Arab Univ. J. Agric. Sci., Ain Shams Univ., Cairo, 14(2), 711-719, 2006

\title{
HEALTHY MODIFIED ZABADY
}

[45]

\author{
El-Demerdash ${ }^{1}$, M.E.; Eman, L. Moustafa ${ }^{1}$ and M.E. Hashem ${ }^{1}$
}

\begin{abstract}
Buffaloe's milk was used for the manufacture of Zabady. Control, Zabady made by using $3 \%$ of the regular starter. $1.5 \%$ of the regular Zabady starter was added to the other three parts, then $1.5 \%$ of Bifidobacterium bifidium, ABT or autolyzed $S$. thermophilus were added to the other three parts respectively. The result showed an increase in acidity of control zabady, while bifidobacterium decreased the acidity and curd tension, and increased $\mathrm{pH}$ value, coagulation time and synersis. Organoleptic properties showed an improve in the flavour of zabady by using bifidobacterium in the end of storage compared to the other treatments.
\end{abstract}

Keywords: Zabady, Probiotic, Bifidobacterium, Acidophilus, Autolyzed S. thermophilus

\section{INTRODUCTION}

Zabady is the most popular fermented dairy products in Egypt. The importance of zabady in human diet is determined by its nutritive and caloric values and health effects (El-Atawy et al 2001).

Recent epidemiological evidences support to protective effects of dairy foods and probiotic bacteria against some cancer diseases. Zabady is manufactured with Streptococcus thermophilus and Lactobacilus delbeuckii subsp bulgaricus. These bacteria nither inhibit the human and animal intestinal tract nor survive in large numbers during passage through the digestive tract.

Recently, there was an increase interest in the incorporation of L. acidophilus and Bifidobacterium species into fermented milk products (Klaver et al $\mathbf{1 9 9 3}$ and Tawfik 1993). These probiotic ef- fects are generally related to inhibition of pathogenic species, treatment of diarrhea, reducing the risk of colon cancer, increasing the immune response system and decreasing concentration of cholesterol in blood plasma (Havenaar and Huis 1992 \& Tawfik, 1993).

Also autolyzed starter culture was added to the normal starter in the manufacture of cheese (Nasr, 1983).

The present study aimed to manufacture healthy zabady by mixing the regular zabady starter with Bifidobacterium, ABT and autolyzed $S$. thermophilus to enhance the nutritive values of zabady.

\section{MATERIAL AND METHODS}

Milk.

Fresh buffaloe's milk was obtained from the herd of Animal Production Research Institute, Egypt.

1. Dairy microbiology Department, Animal Production Research Institute, Agriculture Research Center, Doki, Giza, Egypt

(Received April 18, 2006)

(Accepted May 10, 2006) 


\section{Starters}

Steptococcus thermophilus, Lactobacillus delbreukii subsp bulgaricus, Bifidobacterium befidium,L. acidophilus and ABT were obtained from Ch. Hanson's Lab., Copenhagen, Denmark.

Preparation of autolyzed culture of $S$. thermophilus

Old culture of S.themophilus was prepared as autolyzed starter according to (Dyachenko et al 1970). The pure strain was inoculated to sterilized skim milk under aseptic condition. Incubation was carried out at $38^{\circ} \mathrm{C}$ for 7 days.

\section{Manufacture of Zabady}

Zabady was manufactured from buffalo's milk heat treated at $\left(85^{\circ} \mathrm{C} / 15 \mathrm{~min}\right)$. The milk was divided to four portion. The first was served as control of zabady by using $3 \%$ of the regular starter. The other three portion were inoculated with $1.5 \%$ of the regular zabady starter then $1.5 \%$ of Bifidibacterium bifidium, ABT and autolyzed S. thermophilus were added to the other three portions respectively.

\section{Methods of analysis}

Total solid, Total protein and titratable acidity percent were determined according to the methods described by (IDF 1986). $\mathrm{pH}$ value was measured by using laboratory microprocessor $\mathrm{pH}$ meter model. Hanna HI 852. Curd tension was determined according to El-Shabrawy (1973) using modified westphal balance. Synersis was determined by the methods described by Mehanna and Mehanna (1989).
Lactic acid bacterial count was conducted according to Lee et al (1974). Yeast\& moulds were determined according to Blanchette et al (1996) using modified MRS agar (Oxoid)

Bifidobacterium befidium was enumerated according to Dave and Shah (1996) using modified MRS agar supplemented with $0.05 \%$ L. cystein. $\mathrm{HCl}$.

Organoleptic properties were evaluated by panelists according to the scoring sheet outlined by Nelson and Trout (1956)

All the treatments analysed when fresh and after storage period for 4,8 and 12 day at $5^{\circ} \mathrm{C} \pm 2^{\circ} \mathrm{C}$. Only microbiological analysis were analysed after 4,8,12 and 16 days.

\section{RESULTS AND DISCUSSION}

Chemical composition of fresh zabady is shown in Table (1). It is cleared from the results that TS\%, Fat\% and total protein content did not affect with the type of starter cultures used in all treatments compared with control zabady.

Table1. Effect of different starter cultures on Chemical composition of fresh zabady

\begin{tabular}{|cccc|}
\hline Treatments & T.S\% & Fat\% & T.P\% \\
\hline Control & 17.34 & 4.40 & 4.79 \\
T1 & 17.67 & 4.46 & 4.70 \\
T2 & 17.70 & 4.44 & 4.80 \\
T3 & 17.67 & 4.36 & 4.87 \\
\hline
\end{tabular}

T1: zabady with Bifidobacterium bifidium

T2: zabady with ABT culture

T3: zabady with $S$. thermophilus autolyzed 
This may be due to the same chemical composition in the initial milk used in the manufacture of zabady.

Table (2) shows the effect of using different types of starter culture on titratable acidity\% and $\mathrm{pH}$ value when fresh and during storage period at $5^{\circ} \mathrm{C} \pm 2^{\circ} \mathrm{C}$ for 12 days. The data indicated that acidity increased and $\mathrm{pH}$ values decreased with increasing storage period in all treatments. These results are in agreement with the finding Mehanna and Gonc(1988) and El-Shibiny et al (2005) who mentioned that yoghurt acidity and $\mathrm{pH}$ changes on fresh yoghurt and during storage.

Also, the data showed that the rate of developing both acidity and $\mathrm{pH}$ value during storage were less in case of zabady made with bifidob acterium. These results are in accordance with the finding of ElShibiny et al (2005).

Table 2. Effect of different starter cultures on titratable acidity and corresponding $\mathrm{pH}$ during the storage period of zabady

\begin{tabular}{|ccccccccc|}
\hline \multirow{2}{*}{ Treatments } & \multicolumn{4}{c|}{ T.A } & \multicolumn{5}{c|}{$\mathrm{pH}$} \\
\cline { 2 - 8 } & fresh & 4 days & 8 days & 12 days & fresh & 4 days & 8 days & 12 days \\
\hline Control & 0.79 & 0.84 & 0.89 & 0.98 & 4.86 & 4.77 & 4.71 & 4.59 \\
T1 & 0.75 & 0.77 & 0.83 & 0.89 & 4.96 & 4.87 & 4.80 & 4.71 \\
T2 & 0.78 & 0.80 & 0.85 & 0.92 & 4.90 & 4.84 & 4.78 & 4.67 \\
T3 & 0.77 & 0.78 & 0.85 & 0.88 & 4.93 & 4.82 & 4.79 & 4.64 \\
\hline
\end{tabular}

Table (3) shows the effect of using different types of starter cultures on some rheiological properties of zabady

It is cleared from the data that, the coagulation time of zabady affected with starter culture type. The longest coagulation time recorded when befidobacterium used (T1) while, the shortest recorded when autolyzed $S$. thermophilus used (T3) compared to control and the other treatment (T2). This may be related to the development of acidity during the incubation period. These results are in agreement with those reported by Marshall (1982) and Peri et al (1995).

Also, the same Table (3) showed that the curd tension of zabady when fresh affected with type of starter culture. Curd tension of zabady made by using Bifidobacterium recorded the lowest while curd tension of zabady made with autolyzed $S$. thermophilus recorded the lowest may be due to the ability of the different starter culture to produce lactic acid and the capability to coagulate the milk ElGarawany (2004).

The effect of using different starter culture on the synersis of zabady when fresh and during storage period at $5^{\circ} \mathrm{C} \pm 2{ }^{\circ} \mathrm{C}$ for 12 days are shown in the same Table (3).

It is obvioued from the data that the synersis of all the treatments decreased with storage period may be due to increasing the water binding capacity of protein when stored at $5^{\circ} \mathrm{C} \pm 2^{\circ} \mathrm{C}$ which led to decrease in synersis. These results are in accordance with the finding of Lorenzen et al (2002) and Abou El-Nour et al (2004). 
Table 3. Effect of different starter cultures on rheiological properties of zabady

\begin{tabular}{|ccccccc|}
\hline & & \multicolumn{5}{c|}{ Synersis } \\
Treatments & Coagulation time & Curd & \multicolumn{5}{c|}{ Storage period (days) } \\
\cline { 4 - 7 } & & tension & $\mathbf{0}$ & $\mathbf{4}$ & $\mathbf{8}$ & $\mathbf{1 2}$ \\
\cline { 4 - 7 } & 180 & 79.79 & 20 & 16 & 14 & 11 \\
Control & 195 & 67.53 & 24 & 23 & 19 & 15 \\
T2 & 185 & 82.31 & 22 & 20 & 18 & 17 \\
T3 & 170 & 83.05 & 18 & 17 & 16 & 13 \\
\hline
\end{tabular}

The variation in fatty acids content between the different treatments of zabady as affected by using different types of starter cultures when fresh and after 12 days of storage are shown in Table (4). In general one could say that almost saturated fatty acids increased and unsaturated fatty acids decreased during storage. The rate of changes showed the lowest when bifidobacterium used due to the lowest rate of acidity development. It was clear that the short chain saturated fatty acids Caprillic $\left(\mathrm{C}_{8}\right)$ and the long chain saturated fatty acids Stearic $\left(\mathrm{C}_{18}\right)$ which represented the higher percent of the estimated saturated fatty acids showed the same trend as they decreased by using bifidobacterium and increased by advancing storage.

Concerning the unsaturated fatty acids, it was obvious that Oleic acid $\left(\mathrm{C}_{18: 1}\right)$ which had the highest ratio compared to the other obtained unsaturated fatty acids markedly decreased during storage. The rate of decreasing was the lowest when bifidobacterium used. These results are in agreement with those reported by $\operatorname{Alm}(1982)$ and Shalaby et al (1992) who mentioned that, some fatty acid were increased whereas others decreased according to manufacturing methods. Also, they revealed that fatty acids profile changed during fermentation .They reported that the relative amount of fatty acids increased, whereas quantities of Oleic, Linoleic and Palmitolic acids decreased.

Effect of using different starter culture on the organoleptic properties of zabady when fresh and during storage period at $5^{\circ} \mathrm{C} \pm 2^{\circ} \mathrm{C}$ for 12 days are shown in Table (5). The obtained data showed that flavour of all the treatments affected by the type of starter culture used.

Flavour of control zabady and zabady made with ABT starter culture gained the highest score when fresh compared with the other treatments while zabady made with bifidobacterium had the lowest falvour score .Flovour of all treatments decreased with storage except that made with Bifidobacterium which had constant flavour score with storage to be the highest score after 12days of storage.

Body \&texture of control zabady and T3 were the highest when fresh. Body \& texture of all treatments decreased with increasing storage period. 
Table 4. Effect of different starter cultures on fatty acids of zabady when fresh and at the end of storage.

\begin{tabular}{|ccccccccc|}
\hline Fatty & \multicolumn{2}{c}{ Control } & \multicolumn{2}{c}{ T1 } & \multicolumn{2}{c|}{ T2 } & \multicolumn{2}{c|}{ T3 } \\
\cline { 2 - 9 } acids & Fresh & 12days & Fresh & 12days & Fresh & 12days & Fresh & 12days \\
\hline C4 & - & 1.916 & - & 0.901 & - & 1.171 & - & 1.240 \\
C6 & - & 1.808 & - & 0.861 & - & 0.936 & - & 1.062 \\
C8 & - & 0.604 & 0.658 & 1.360 & - & - & 0.482 & 0.634 \\
C10 & - & 1.696 & 1.514 & 1.834 & - & - & 1.277 & 1.545 \\
C12 & 2.484 & 2.662 & 2.152 & 2.359 & 2.11 & 2.615 & 2.300 & 2.579 \\
C14 iso & - & 0.259 & - & 0.286 & 1.470 & - & - & 0.295 \\
C14 & 12.255 & 12.445 & 11.812 & 12.087 & 12.419 & 12.119 & 12.750 & 12.921 \\
C14:1 & 1.972 & 1.341 & 1.198 & 1.031 & 1.264 & 0.907 & 1.553 & 1.036 \\
C15 & 1.498 & 1.663 & 1.648 & 1.685 & 1.679 & 1.715 & 1.768 & 1.821 \\
C16 iso & 2.134 & 2.561 & 1.655 & 2.120 & 2.326 & 2.554 & 2.031 & 2.194 \\
C16 & 33.912 & 34.291 & 35.397 & 36.065 & 34.935 & 36.905 & 31.940 & 32.243 \\
C16:1 & 2.948 & 1.563 & - & 1.196 & 1.268 & 0.967 & - & 0.367 \\
C17 & - & 0.796 & - & 0.803 & 0.757 & 0.837 & - & 0.783 \\
C18 & 16.806 & 17.312 & 16.944 & 17.412 & 15.143 & 16.357 & 14.976 & 15.863 \\
C18:1 & 25.828 & 19.354 & 27.152 & 20.254 & 25.957 & 24.305 & 31.641 & 25.788 \\
\hline
\end{tabular}

Table 5. Effect of different starter cultures on organoleptic properties of zabady

\begin{tabular}{|cccccc|}
\hline & & \multicolumn{5}{c|}{} \\
\cline { 3 - 6 } Treatments & Age & Flavour & Body\&Tex. & App. & Total \\
& & 50 & 40 & 10 & 100 \\
\hline Control & & 48 & 39 & 9 & 96 \\
T1 & \multirow{2}{*}{ Fresh } & 46 & 35 & 9 & 90 \\
T2 & & 48 & 38 & 10 & 96 \\
T3 & & 46 & 39 & 9 & 94 \\
Control & & 47 & 38 & 9 & 94 \\
T1 & 4 & 46 & 36 & 9 & 91 \\
T2 & & 47 & 38 & 9 & 94 \\
T3 & & 45 & 39 & 9 & 93 \\
Control & & 43 & 36 & 9 & 88 \\
T1 & 46 & 34 & 8 & 88 \\
T2 & 8 & 45 & 36 & 9 & 90 \\
T3 & & 43 & 36 & 8 & 87 \\
Control & & 41 & 35 & 8 & 84 \\
T1 & \multirow{2}{*}{12} & 46 & 31 & 7 & 84 \\
T2 & & 44 & 33 & 8 & 85 \\
T3 & & 39 & 33 & 8 & 80 \\
\hline
\end{tabular}

Arab Univ. J. Agric. Sci., 14(2), 2006 
Highest appearance score recorded when ABT starter culture used in the manufacture of zabady when fresh. Appearance tended to decrease with storage. Total score of zabady made from ABT was closed with traditional zabady when fresh. Total score of all the treatments decreased with increasing storage period.

Similar trends were reported by Kebary and Hussein (1999); Hassan et al (1999) and El-Garawany (2004).

Data present in Table (6) shows that lactic acid bacteria count (L.A.B) were increased gradually until reach 8 days, then decreased after 12 and 16 days. These results are in agreement with the finding of Badawi et al (2004) and ElAtawy et al (2001). In the same it could be seen that table mould and yeast did not detect in all treatments when fresh and during storage except control which detected after 12 and 16 days and in all treatments after 16 days. These may be due to the contamination which occurred during storage.

Table 6. Growth of lactic acid bacteria, moulds \& yeasts and Bifidobacterium in zabady from different starter cultures during storage period

\begin{tabular}{|c|c|c|c|c|c|c|c|c|c|}
\hline \multirow{3}{*}{ Treatment } & \multicolumn{9}{|c|}{ Storage periods (days) } \\
\hline & \multicolumn{3}{|c|}{ Fresh } & \multicolumn{3}{|c|}{4} & \multicolumn{3}{|c|}{8} \\
\hline & L.A.B & M\&Y & Bif. & L.A.B & M\&Y & Bif. & L.A.B & M\&Y & Bif. \\
\hline Control & 4 & N.D & 10.5 & 10.5 & N.D & 18.6 & 18.4 & N.D & 14.7 \\
\hline $\mathrm{T} 1$ & 6.2 & N.D & 15.0 & 15.0 & N.D & 20.1 & 20.1 & N.D & 18.2 \\
\hline $\mathrm{T} 2$ & 8.6 & N.D & 17.3 & 17.3 & N.D & 21.9 & 21.9 & N.D & 19.5 \\
\hline \multirow[t]{3}{*}{$\mathrm{T} 3$} & 4.7 & N.D & 11.3 & 11.3 & N.D & 19.1 & 19.1 & N.D & 15.3 \\
\hline & \multicolumn{3}{|c|}{12} & \multicolumn{3}{|c|}{16} & & & \\
\hline & L.A.B & M\&Y & Bif. & L.A.B & M\&Y & Bif. & & & \\
\hline Control & 14.7 & N.D & - & - & 6.21 & - & & & \\
\hline $\mathrm{T} 1$ & 18.2 & N.D & 22.7 & - & 4.37 & 22.7 & & & \\
\hline $\mathrm{T} 2$ & 19.5 & N.D & 18.2 & - & 5.10 & 18.2 & & & \\
\hline $\mathrm{T} 3$ & 15.3 & N.D & - & - & 4.00 & - & & & \\
\hline
\end{tabular}

The count of Bifidobacterium was higher in $\mathrm{T} 1$ than $\mathrm{T} 2$ this due to the type of starter which used for T1 and T2. Also count of Bifidobacterium increased during the storage period until 8 days then decreased at 12 and 16 days.

These results are in agreement with those reported by Abou Dawood (2002) who reported that Bifidobacterium maintained their viability in Kareish cheese $\left(>10^{6} \mathrm{cfu} / \mathrm{g}\right)$ till the end of storage period (10days).

\section{REFERENCES}

Abou Dawood, S.A.I. (2002). Survival of nonencapsulated and capsulated Bifidobacterium in probiotic Karish cheese. Egyptian J. Dairy Sci., 30: 43-48. 
Abou El-Nour, A.M.; A.M. El-Kholy and M.H. Abd El-Salam(2004). Rheological properties of cows milk yoghurt treated by transglutaminase (TGASE). Egyptian J. Dairy Sci., 32: 73-86.

Alm, L. (1982). Effect of fermentation on curd size and digestibility of milk proteins in vitro of Swedish fermented milk products. J. Dairy Sci., 65: 509-515.

Badawi, R.M.; K.M.K. Kebary and S.A. Hussein (2004). Impact of substituting non-fat dry milk with pectin on cow's milk yoghurt quality. Proc. $9^{\text {th }}$ Egyptian Conference for Dairy Science and technology. Cairo, (10): 133-151.

Blanchette, L.; D. Ray; G. Belanger and S.F. Gauthier (1996). Production of Cottage cheese using dressing fermented by Bifidobacterium. J. Dairy Sci.,79: 813.

Dave, R.I. and N.P. Shah (1996). Evaluation of media for selective enumeration of Streptococcus thermophilus, Lactobacillus delbrueckii spp. bulgaricus, Lactobacilus acidophilus and Bifidobacterium. J. Dairy Sci., 79(9): 1529-1536.

Dyachenko, P.F.; T. Nassib and E.V. Schedushmov (1970). Culturing of thermophilus lactic acid bacteria in media neutralized with marble. Mol. Prom. 31(6): 14-16.

El-Atawy, Z.A.; L.M. Mohamed and E.L. Mostafa (2001). Dietetic yoghurt enriched with fenugreek. Egyptian $\boldsymbol{J}$. Biomed. Sci., 8: 96-103.

El-Garawany, G.A. (2004). Preparation and properties of calcium enriched yoghurt from cow's milk. Egyptian J.Dairy Sci., 32: 59-72.

El-Shabrawy, E.A. (1973). Studies on Cashcaval Cheese Made from Buffaloe's Milk. pp. 47-58. M.Sc. Thesis, Fac. of Agriculture, Ain Shams Univ. Cairo.
El-Shibiny, S.; M.M. Metwally; S. Abd El-Ghani; A.M. Abd El-Fattah and A.Y.M. Okda (2005). Manufacture of some probiotic dairy products from ultrafiltration milk retentate. Egyptian $J$. Dairy Sci., 33: 215-227.

Hassan, F.A.M.; W.A. Helmy and A.E Enab (1999). Utilization of some local poly saccharid in manufacture of yoghurt. Egyptian J. Dairy Sci., 27: 281-290.

Hanevnaar, R. and M.J.H. Huis (1992). Probiotic: A General View In: Lactic Acid Bacteria in Health and Disease. Vol. I. pp. 123-137. Amsterdam: Elsevier Applied Science Publishers.

IDF (International Dairy Fedration Standerd) (1986). Milk Determination of Nitrogen Content (Kjeldahl Method) and Calculate of Curd Protein Content. IDF Standard 20A.

Kebary, K.M.K and S. Hussein (1999). Manufacture of low fat zabady using different fat substitutes. Acta Alimentaria, 28: 1-13.

Klaver, F.A.M.; F. Kingma and A.H. Weerkamp (1993). Growth and survival of Bifidobacteria in milk. Neth. Milk Dairy J. 42:151-166.

Lee, S.Y.; E.P. Vedamuthu; C.J. Washam and G.W. Reinbold (1974). An agar medium for the differential enumeration of yoghurt starter bacteria. J. Milk and Food Tech. 37: 272 -285.

Lorenzen, P.C.; Chr. H. Neve and E. Schlimme (2002). Effect of enzymatic cross linking of milk proteins on functional properties of set style yoghurt. Int. J. Dairy Tech. 55: 150-152.

Marshall, R.J. (1982). An improved method for measurement of the synersis of curd formed by rennet action on milk. J. Dairy Res. 49: 329-342 . Mehanna, N.M and S.Gonc (1988). Manufacture of yoghurt from milk forti- 
fied with whey powder. Egyptian $\boldsymbol{J}$. Dairy Sci., 18: 425-431.

Mehanna, N.M. and A.S. Mehanna (1989). On the use of stabilizer for improving some properties of cow's milk yoghurt. Egyptian J. Dairy Sci. 17: 289304.

Nasr, M. (1983). Acceleration of Romi cheese ripening by addition of fungal esterase Upase powder. Egyptian $\boldsymbol{J}$. Dairy Sci., 11: 309-313 .

Nelson, J.A and G.M. Trout(1956). Judging Dairy Production $4^{\text {th }}$ Ed., 280-
285. The Olsen Publishing Co. Milwoukee Wis. 53212.USA.

Peri, C.; M. Lucisamo and E.Douat, (1995). Studies on coagulation of milk ultrafiltration ii- kinitics of whey synersis. Milchwissen. 40: 650-657.

Shalaby, S.; M. El-Shobery and E. ElNagar (1992). Nutritional evaluation of zabady. Egyptian J. Food Sci. 20(3) 331340.

Tawfik, N.F. (1993). Survival of Bifidobactreim bifidium in probiotic fermented milks. Egyptian J. Appl. Sci., 8: 85-92.

\section{بحلة اتحاد الجامعات العربية للدراسات والبحوث الزراعية، جامعة عين شمس، القاهرة، 14(2)، 711-719، 2006

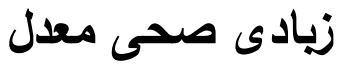

[45]

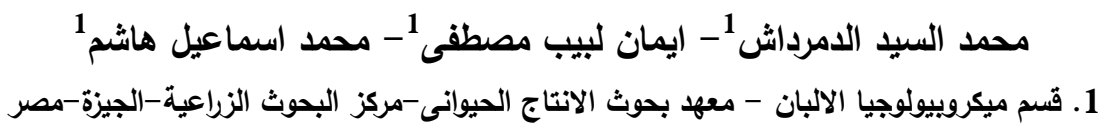

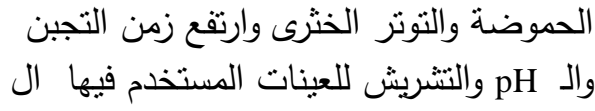
التهانة Bifidobacterium العينة (T3) فكانت اقل تشريش 0 كما وضح عدم ظهور الاحماض الدهنية قصيرة السلسة

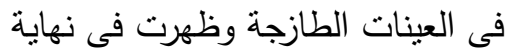

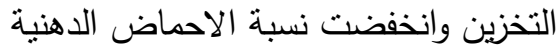

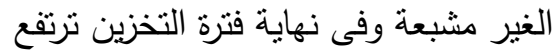

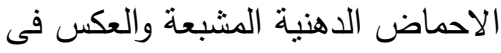
العينات الطازجة.

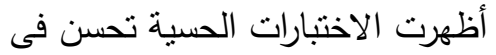

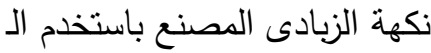

تم تصنيع الزبادى من لبن جاموسى حيث

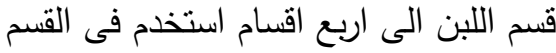

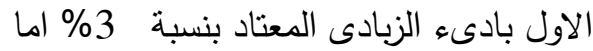
الاجزاء الثلاثة الاخرى نم اضافة بادى الادئ الزبادى بنسبة 1.5\% لكل منها ثم اضافة

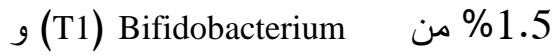
autolyzed والبادى المتحلل من (T2)ABT (T3)S. على التوالى للاقسام

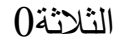

$$
\begin{aligned}
& \text { أظهرت النتائج ثبات البروتين والدهن }
\end{aligned}
$$

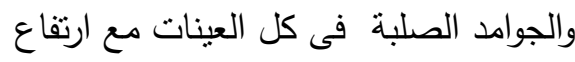

$$
\begin{aligned}
& \text { حموضة عينة الكنترول بينما انخفضت كلينات التينات }
\end{aligned}
$$




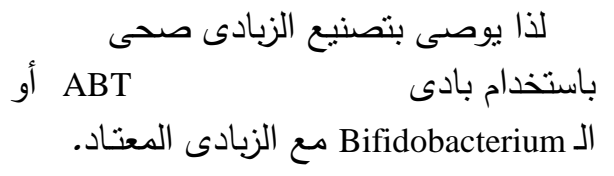
(T1) Bifidobacterium ) فى نهاية فترة التخزين مقارنة بالمعامالات الاخرى ، كما

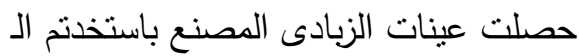 ( T2) ABT

تحكيم: ا.د محمد عاطف الغندور ا.د السيد عبدالرافع محمد الدمد الفدور 